\title{
Religious Teaching and Learning in Minority Muslim of Manado Indonesia
}

\author{
Ismail Suardi Wekke \\ Sekolah Tinggi Agama Islam Negeri Sorong \\ Sorong, West Papua, Indonesia \\ iswekke@gmail.com
}

\author{
Sabil Mokodenseho \\ Institut Agama Islam Negeri Manado \\ Manado, North Sulawesi, Indonesia
}

\begin{abstract}
Tolerance is the pillar in society life, but it has ambivalent power manifested in two forms are solid and democratic forms. Therefore, it is a need to explore the practical religious learning. The Manado city is a location where Muslim is minority. This condition reflects that there is encounter between religions and faiths. This paper was conducted in State Senior High School 9 of Manado, North Sulawesi. The study shows that tolerance invites dialogs to communicate the existence of mutual recognition. Being tolerant is letting or permitting others to be themselves, respecting for others regardless of their origins and their backgrounds.
\end{abstract}

\section{Keywords: learning material, public school, minority Muslim}

\section{INTRODUCTION}

Ali Maksum illustrates that the Indonesian nation is a nation whose society is very plural or pluralist. The plurality of Indonesian nation can be seen from two perspectives, namely horizontal and vertical. In a horizontal perspective, the plurality of our nation can be seen from different religions, ethnic, regional, geographical, clothing, food and culture. While in a vertical perspective, the pluralism of our nation can be seen from different levels of education, economy, settlement, occupation, and socio-cultural level [1].

The role of humanist education that promotes human values in the context of humanizing human beings becomes very important in providing profound interpretation of the diversity bases as a social reality that must be accepted by every Indonesian. This requires that in developing the curriculum of educational institutions should pay attention to the dimensions of diversity and plurality. That is, the diversity of society can influence educators in determining concepts, objectives, content, and approaches in developing an education [2].

Religion teaches tranquility, harmony and peace [3], as well as, obviously emerges positive synergy in religious life. But, there are conflicts, disputes and even violence often found happening because of or on behalf of religion [4], [5]. Even the more troubling trend is that the conflicts are happening between members of religions which have various sects [6], [7]. This was emerging amid the condition of the nation which was confronted by problems and protracted crises in the various fields of life, including crisis in education world. Whereas peace is all humans' desires [8], [9]. Chaos which often happens between religious communities was caused by the lack of religious awareness [10].

Islamic Religious Education in school serves first for the development of faith and devotion to Allah swt and noble morals learners as optimal as possible who have been invested in the family first. The second planting the value of Islamic teachings as a guide to achieve the happiness of life in the world and in the afterlife. The three mental adjustments of learners to the physical and social environment through Islamic Religious Education. Fourth improvement mistakes, weaknesses of learners in the belief, the practice of Islamic teachings in everyday life. The five prevention of learners from the negative and foreign cultures that will be faced daily. The six teachings on religious science in general, system and functional. Seventh channeling of students to explore religious education to higher levels [11].

Violence is happening continuously, started from vertical problems but then intersected with horizontal issues which, in this term, were issues of ethnicity and religion. The case between religious communities did not necessarily happen if they could respect each other and respect their freedom as well as aware of that the differences were not an obstacle in realizing the brotherhood between them [12]-[15]. This paper would identify religious relationship in Islamic Lesson in Public Senior High School 9 of Manado.

\section{METHOD}

This research applied qualitative approach. Data appointed were not in numeric form but taken from interview texts and field notes, so that the objectives of this qualitative research was to describe empirical reality behind the phenomenon in deep, detailed and completed manners [16], [17]. The qualitative research method used was naturalistic research which was done in natural condition [18], [19]. This research was done for approximately two (2) months, started from July 2016 until August 2016 in State Senior High School 9 of Manado, the District of Malalayang, Manado City, North Sulawesi. It was done based on a consideration that the school had typical characteristics which were in accordance with problems observed. Data collection was performed using 2 methods were interview and observation. Interviews were conducted using same questions to 18 respondents consisting of one teacher of Islamic religious lesson, one teacher of Christian religious lesson, one teacher of Catholic religious' 
lesson, five Islamic students, five Christian students and five Catholic students.

\section{RESULTS AND DISCUSSION}

In relation with Islamic learning process, the most important thing should be implemented in embedding values of religious tolerance in Islamic lesson in State Senior High School 9 of Manado was material presentation. The tolerance was done by mutual respect and giving the freedom each other to implement their teachings of religion without any disturbance from others.

The teacher should also ensure the students that the diversity of humans in term of their religions and faiths. Therefore, it is not justified to coerce other to embrace Islam. Besides learning material, teacher capability to present materials about religious tolerance was also required to get the students understand the materials completely. This became a difficult problem for the teacher since the students were not only individuals with all their uniqueness, but also as social beings with various backgrounds. At least, three aspects were distinguishing a student from others; intellectual, psychological and biological aspects. The researcher saw that in State Senior High School 9 of Manado, teachers' capability of presenting materials about religious tolerance in Islam was very good since it was supported by moderate religious concept. This can be seen when the teacher was explaining to the students about QS Yunus (10: 99) and its content and hadith narrated by Bukhari which tells that when the Prophet Muhammad SAW and his companions were in a forum, a group of Jewish people carrying a dead body passed in front of them. The prophet stood up immediately to get tribute upon the dead body. One of companions said, "They are Jews, O Prophet. Aren't they?" The Prophet said, "But they are also humans."

It was clear that belief or theological viewpoint was not human's business but Allah's. There was no compromise or tolerance in this context. But Muamalah (human interaction) was in the context of humanity. In addition to that, the researcher also observed the embedding process of the values of religious tolerance within Islamic lesson in State Senior High School 9 of Manado, which was done by giving the students chances to follow religious lessons appropriately with their respective religions, creating learning atmosphere with religious diversity, building mutual trust among them, keeping mutual understanding each other, upholding mutual love, going deep into materials about tolerance and guiding and giving motivation to the students in doing activities relating to tolerance as by not discriminating Muslim and non-Muslim students.

Islamic education which was a sub-system of national education system was one of most effective media to generate generation which has an insight which is able to take the diversity as a part which should be appreciated constructively [20]-[22]. Therefore, which this learning atmosphere, the students were expected to be able to develop Tasamuh attitude both in the school and in the society.
Learning strategy used by the teachers was cooperative teaching learning in social intercourse which had various properties and be able to create pleasant atmosphere [23][25]. Cooperative learning process would encourage the students to study about positive sides form their friends. In turn, they would be conditioned within the learning process where a student is studying together with others in the atmosphere containing mutual respect, tolerant and understanding each other [26], [27].

Along with advances in technology, learning media had significant influence on the development of education in schools, so that the learning tools or media should be adjusted to such advances technology. Moreover, the use of media of technology made the learning process to be more effective and efficient. Not only that, the development of education in schools was increasingly changing and encouraging various efforts to change. As for the learning media used to embed values of religious tolerance in religious lessons in State Senior High School 9 of Manado were curriculum, supporting textbooks, print media, electronic media (laptop and projector), audio-visual media and internet network [28].

Tolerance between various religious people was one of important issues in Islamic theological system [29], [30]. To foster this attitude, education, mainly Islamic education, was the most appropriate way to sow the seeds of tolerance, life harmony and sincere appreciation to the reality of the diversity of cultural-religious aspect of the community. Since Islamic education was a sub-system of national education which was the most effective medium to generate a generation having an insight that is able to make the diversity to be a part which should be appreciated constructively.

The concept of peace in Islam is very clear and resolute because the word Islam itself is etymologically derived from the word aslamayuslimu-islam which means submission, also peace which can mean total submission to God and peace with fellow human beings as well as a sense of peace with God [2]. Islam in this terminology means to bring man to salvation and peace, both to God and to his fellow beings. Peace can also mean the norm, a value derived from the unity and universality of God, a value system and a manifestation of the unity of God into human life and society [31].

\section{CONCLUSION}

The Government's role in this term, until now, has not been appropriately done to manage conflicts, both using political and legal approaches which are partial approaches which have potential to create new problems emerging from people dissatisfaction with court rulings. Religious lesson is one of appropriate solutions to solve protracted conflicts due to its role as social reconstruction agent. Moreover, teacher should consider to methods used in learning process, to let the students understand completely what the teacher delivers.

In addition, facilities of educational institutions should be improved, given that the success of education is inseparable from facilities available. Moreover, teachers must be willing to transform themselves as well as possible to guide and teach by 
promoting the values of tolerance. The implementation of multicultural education emphasizing on the importance of the awareness of the existing diversity needs commitments of all elements of the community since all need educational paradigm reformation.

\section{REFERENCES}

[1] R. Rahim, "Signifikansi pendidikan multikultural terhadap kelompok minoritas,” Anal. J. Stud. Keislam., vol. 12, no. 1, pp. 161-182, 2017.

[2] S. S. Pettalongi, "Islam dan Pendidikan Humanis dalam Resolusi Konflik Sosial," J. Cakrawala Pendidik., no. 2, 2013.

[3] Z. Baidhawy, "Building harmony and peace through multiculturalist theology-based religious education: an alternative for contemporary Indonesia," Br. J. Relig. Educ., vol. 29, no. 1, pp. 15-30, 2007.

[4] A. Fernández-Savater, C. Flesher Fominaya, L. Carvalho, Çiğdem, H. Elsadda, W. El-Tamami, P. Horrillo, S. Nanclares, and S. Stavrides, "Life after the squares: reflections on the consequences of the Occupy movements," Soc. Mov. Stud., vol. 16, no. 1, pp. 119-151, 2017.

[5] M. E. Gürbüz and M. Bernstein, “'Thou Shall not Protest!': MultiInstitutional Politics, Strategic Nonconfrontation and Islamic Mobilizations in Turkey," in Nonviolent Conflict and Civil Resistance, Emerald Group Publishing Limited, 2012, pp. 63-91.

[6] J. D. Davidson and R. E. Pyle, "Religious Stratification in America," in Religion, Work and Inequality, Emerald Group Publishing Limited, 2012, pp. 3-25.

[7] A. Davis, "Defending religious pluralism for religious education," Ethics Educ., vol. 5, no. 3, pp. 189-202, 2010.

[8] K. Charsley and M. Bolognani, "Being a freshie is (not) cool: stigma, capital and disgust in British Pakistani stereotypes of new subcontinental migrants," Ethn. Racial Stud., vol. 40, no. 1, pp. 43-62, 2017.

[9] C. J. Craig, "Narrative inquiry in teaching and teacher education," in Narrative inquiries into curriculum making in teacher education, Emerald Group Publishing Limited, 2011, pp. 19-42.

[10] R. Stark, E. Hamberg, and A. S. Miller, "Exploring spirituality and unchurched religions in America, Sweden, and Japan," J. Contemp. Relig., vol. 20, no. 1, pp. 3-23, 2005.

[11] H. Samiun, D. Budimansyah, and C. Darmawan, "FORMING STUDENT CHARACTER THROUGH CIVIC EDUCATION LEARNING MODEL BASED PORTFOLIO IN SMP AL-WATHAN AMBON," Civ. J. Pendidik. KEWARGANEGARAAN, vol. 18, no. 2, 2014.

[12] B. de Muynck, P. Vos, J. Hoogland, and J. Van der Stoep, "A Distinctive of Christian Higher Education: Educating for Vocation." Taylor \& Francis, 2017.

[13] D. DiSalvo and J. E. Copulsky, "Faith in the Primaries," Perspect. Polit. Sci., vol. 38, no. 2, pp. 99-106, 2009.

[14] A. Elbasani and O. Roy, "Governing Islam and Religious Pluralism in New Democracies." Taylor \& Francis, 2017.

[15] D. Vicky Duckworth and Dr Jonathan Tummons and F. Farrell, "A critical investigation of the relationship between masculinity, social justice, religious education and the neo-liberal discourse," Educ. Train., vol. 56, no. 7, pp. 650-662, 2014.

[16] W. R. Molasso, "Theoretical frameworks in qualitative research," J. Coll. Character, vol. 7, no. 7, 2006.

[17] S. Reeves, J. Peller, J. Goldman, and S. Kitto, "Ethnography in qualitative educational research: AMEE Guide No. 80," Med. Teach., vol. 35, no. 8, pp. e1365-e1379, 2013.

[18] L. Hallberg, "Some reflections on qualitative research." Taylor \& Francis, 2008.

[19] I. Holloway and L. Todres, "Thinking differently: challenges in qualitative research," Int. J. Qual. Stud. Health Well-being, vol. 2, no. 1, pp. 12-18, 2007.

[20] M. Hagevi, "Religion and the environmental opinion in 22 countries: a comparative study," Int. Rev. Sociol., vol. 24, no. 1, pp. 91-109, 2014.
[21] T. Hjelm, "National piety: Religious equality, freedom of religion and national identity in Finnish political discourse," Religion, vol. 44, no. 1, pp. 28-45, 2014.

[22] A. Woolfolk Hoy, "A reflection on the place of emotion in teaching and teacher education," in Emotion and school: Understanding how the hidden curriculum influences relationships, leadership, teaching, and learning, Emerald Group Publishing Limited, 2013, pp. 255-270.

[23] V. Kazanjian and P. Laurence, "The journey toward multi-faith community on campus: The religious and spiritual life program at Wellesley College," J. Coll. Character, vol. 9, no. 2, 2007.

[24] P. E. Ketelaar, R. Konig, E. G. Smit, and H. Thorbjørnsen, "In ads we trust. Religiousness as a predictor of advertising trustworthiness and avoidance," J. Consum. Mark., vol. 32, no. 3, pp. 190-198, 2015.

[25] Å. Kolås, "Framing the tribal: ethnic violence in Northeast India," Asian Ethn., vol. 18, no. 1, pp. 22-37, 2017.

[26] B. J. Lee, “'It's not paranoia when they are really out to get you': the role of conspiracy theories in the context of heightened security," Behav. Sci. Terror. Polit. Aggress., vol. 9, no. 1, pp. 4-20, 2017.

[27] M. Naughton, A. Habisch, G. Lenssen, and G. Lenssen, "Practical wisdom for turbulent times: exegesis beyond historical and canonical concerns," J. Manag. Dev., vol. 29, no. 7/8, pp. 686-696, 2010.

[28] L. Plowman, "Revisiting ethnography by proxy," Int. J. Soc. Res. Methodol., pp. 1-12, 2016.

[29] I. Allgood, "Faith and Freedom of Religion in US Public Schools: Issues and Challenges Facing Teachers," Relig. Educ., vol. 111, no. 3, pp. 270287, 2016.

[30] A. Chan and M. S. Islam, "State, religion, and environmentalism: fostering social cohesion and environmental protection in Singapore," Environ. Sociol., vol. 1, no. 3, pp. 177-189, 2015.

[31] A. M. Abegebriel and A. Y. Abeveiro, Negara Tuhan: the thematic encyclopaedia. SR-Ins Pub., 2004. 